\title{
A Mini Scale Batch Reactor for the Production of Palm-Based Polyol
}

(Reaktor Kelompok Skala Mini bagi Penghasilan Poliol Poliuretana Sawit)

\author{
KHAIRIAH HAJI BADRI* \& MUHAMMAD SYUKRI NGAH
}

\begin{abstract}
An investigation on a batch production of palm kernel oil polyol (PKO-p) was conducted via esterification and condensation. The process design was thoroughly studied as a preliminary step for future upscaling. The process variables included necessity of vacuum pump, controlling of heating rate, recording the production time, nitrogen gas flow and agitator speed. About 250 mL PKO-p was successfully synthesized within 3 h. Vacuum pressure was applied to haul out moisture from the system. The control of heating rate and production time are vital to avoid sudden oxidation.
\end{abstract}

Keywords: Batch reactor; palm-based polyurethane; palm kernel oil polyol; process design

ABSTRAK

Suatu kajian penghasilan poliol minyak isirong sawit (PKO-p) secara sesekumpul telah dijalankan melalui tindak balas pengesteran dan penyejatan. Reka bentuk proses telah dikaji dengan teliti sebagai langkah awal dalam kajian penskalaan untuk masa hadapan. Pemboleh ubah proses termasuk keperluan pam vakum, pengawalan kadar pemanasan, masa penghasilan yang direkodkan, aliran gas nitrogen dan halaju pengadun. Sebanyak $250 \mathrm{~mL}$ PKO-p telah berjaya disintesis dalam tempoh 3 jam. Tekanan vakum telah digunakan untuk mengeluarkan kelembapan daripada sistem. Pengawalan kadar pemanasan dan masa penghasilan adalah penting untuk mengelakkan pengoksidaan berlaku secara drastik.

Kata kunci: Poliol minyak isirung sawit; poliuretana sawit; reaktor sesekumpul; reka bentuk proses

\section{INTRODUCTION}

Currently, polyols used in the production of urethanes are majorly from petrochemicals. As petrochemicals are ultimately derived from petroleum, they are non-renewable resources. Polyol production requires a great deal of energy, as oil must be drilled and extracted from the ground, transported to refineries and processed to yield the polyol. These required efforts add to the cost of polyol and to the disadvantageous environmental effects of its production. The price of polyol tends to be somewhat unpredictable and exhausted in the near future.

The current issues of awareness on environment, green and environmental-friendly products are getting higher attention and their demand is ever growing. Consumer demand for 'green materials' products continues to grow. The term 'green' polyol for the purpose of this application is meant to be broadly interpreted to signify all polyols not derived exclusively from non-renewable resources. As a result, it would be most advantageous to replace polyols, as used in the production of urethane foams and elastomers, with more versatile, renewable, less costly and more environmentally friendly components (Kurth et al. 2006).

Due to expensive market price of petroleum and the demand for green materials, the studies for polyol production using natural resources seem to be sensibly an alternative. Palm oil which has been termed as the golden crop in Malaysia is used in the production of polyol. Palm kernel oil polyol (PKO-p) is renewable and readily used with lesser impact to the environment compared to polyol from petroleum. Badri et al. $(2005,2004,2000)$ had conducted thorough researches that converted palm kernel oil (PKO) to polyurethane polyol with properties that are comparable to petroleum-based polyol.

Some of the earliest successes in the efforts to replace polyols from natural resources are using castor oil (Benli et al. 1998), soybean oil (Guo et al. 2000), palm oil (Chian \& Gan 1998) and palm kernel oil (Badri et al. 2000). However, these researches do not aim for upscaling and they found that there is no necessity to look at the process control of the syntheses. Badri et al. (2001) have produced polyol (PKO-p) from palm kernel oil (PKO) at laboratory scale. However, the process design and control have not been considered. The scheme for the process used by Badri (2001) is shown in Figure 1.

The production of palm-based polyurethane is one of the most potential and advanced compared with other polymers (Tanaka et al. 2007). Polyurethane (PU) is one of the most versatile polymeric materials which play vital roles in many industries such as coating, elastomer to rigid insulation foams and likewise polyurethane can be found in almost all aspects of life. High market demand for natural-based materials in the production of polyurethane becomes a major factor for commercialization.

A chemical process is composed of a large number of units (reactors, heat exchangers, separators and pumps) 


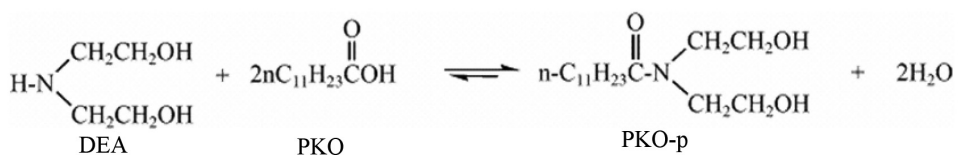

FIGURE 1. Esterification and condensation of palm kernel oil to polyol

which are interconnected with each other through the flow of materials and energy. For such a process the problem of designing a control system is not simple but requires experience, knowledge of basic chemistry and good chemical engineering background. Without dwelling too much on the control problems of integrated chemical processes, this paper will discuss some of their characteristic features of producing palm-based polyurethane polyol in the aspects of its physicochemical properties.

\section{MATERIALS AND METHODS}

Refined, bleached and deodorized palm kernel oil (RBD PKO) was obtained from Lee Oilmills Sdn Bhd, Malaysia. Ethylene glycol (MEG), diethanolamine (DEA) and potassium acetate (PA) were supplied by Merck Sdn Bhd, Malaysia. All chemicals were used without further purification.

\section{PRODUCTION OF PALM KERNEL OIL-BASED POLYOL}

Palm kernel oil-based polyol (PKO-p) was prepared in accordance to the patented process (MY145097-A). The experiment was conducted in a batch reactor unit as shown in Figure 2. Ethylene glycol, diethanolamine and potassium acetate were premixed prior to usage. These chemicals were prepared at 30:3:1 ratio and loaded into the vessel containing palm kernel oil (PKO) at a ratio of 20:80. The mixture was continuously stirred at $100-400$ rpm maintaining the temperature at $190 \pm 5^{\circ} \mathrm{C}$ for $30 \mathrm{~min}$ with nitrogen gas flow throughout the process. The vacuum pressure was analysed at 400-800 mbar. Upon completion of reaction, it was cooled until it reached $80-100^{\circ} \mathrm{C}$ before storage and further analysis.

\section{DESIGN SPECIFICATIONS AND EQUIPMENT}

The design specifications were set as follows:

Conversion product must be achievable above $85 \%$ yield; Compatible materials must be used for the process unit; The safest operation pressure must be considered; Vessel of 2 L maximum capacity was used; Heat transfer was controllable yet minimized to surrounding; and Ideal mixing eventhough it was a batch reactor vessel.

The conversion factor above $85 \%$ was determined in a weight percentage of how much fatty acid esteramide (PKO-p) was earned per liter of palm kernel oil. The material for the vessel was glass and the stirrer was made of aluminum that was compatible to the chemical properties of the oil and the reagents. The heat was supplied by the heating mantle. The agitator power requirement was determined using the relationship between Reynold number, Re and Newton power number for Newtonian fluid (Couper et al. 2012) as follows:

$$
\operatorname{Re}=\frac{n d^{2} \rho}{\mu},
$$

with $d$ as the impeller diameter, $n$ as the rotational speed, $\rho$ and $\mu$ for the density and the viscosity of the

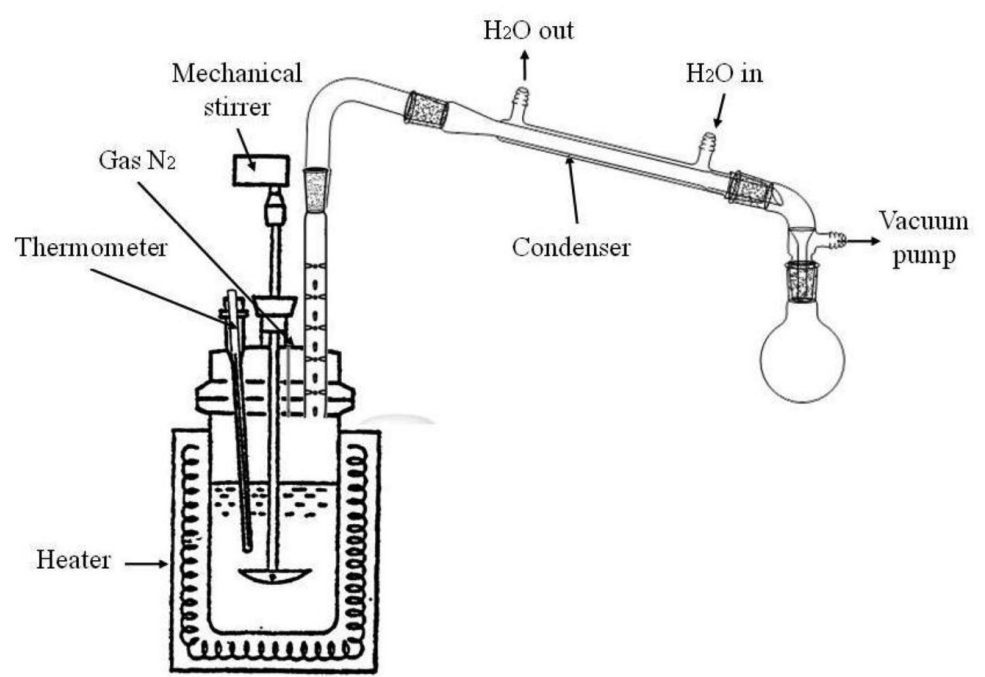

FIGURE 2. Schematic diagram of the laboratory setting for the production of PKO-p 
oil, respectively. The value of $R e$ is used to specify the Newton number, $\mathrm{Ne}$, obtained from the Newton number and Reynold number diagram for a particular region. The motor power required was then calculated using (2):

$$
P=N e \cdot \rho \cdot n^{3} \cdot d^{5} \text {. }
$$

The ideal mixing was approximated that the mixing process was enforced to take place in the near turbulent region. The motor power requirement of $0.24 \mathrm{~kW}$ to easily deliver up to $600 \mathrm{~N} \cdot \mathrm{cm}$ torque energy was then selected for a three-blade marine propeller. The rotational speed varies between 200 and $400 \mathrm{rpm}$. A process heater (heating mantle) of $0.65 \mathrm{~kW}$ were chosen for the esterification and transesterification process. The temperature gradients were recorded using a thermometer.

The operating parameters were varied and as listed in Table 1. The hydroxyl value, cloud point, moisture content, physical appearance and viscosity were determined. A spectroscopy analysis of Fourier transform infrared (FTIR) were conducted as a quick tool to detect the formation of the PKO-p especially shifting of the $\mathrm{C}=\mathrm{O}$ peak of the carboxylic acid (fatty acid) to $\mathrm{C}=\mathrm{O}$ of the ester (esteramide) as well as appearance of carbamate peak (C-N). An FTIR spectrometer Perkin-Elmer model Spectrum BX was used by applying the $\mathrm{NaCl}$ cell technique. The samples were analyzed at 4000 to $700 \mathrm{~cm}^{-1}$.

Physical observation was conducted for several days to ensure that there was no occurrence of phase separation. A Karl Fischer Titrator (KFT) Model 787 KF Titrino was used to determine the moisture content in the samples in accordance to ASTM D4672-91 (Standard Test Methods for Polyurethane Raw Materials: Determination of Water content of Polyol). Methanol anhydride was used as the solvent and Hydranal Composite $5 \circledR$ acts as an indicator.
Analysis on cloud point was performed according to ASTM D117-02 (Standard guide for sampling, test methods and specifications for electrical insulating oils of petroleum origin). The determination of the hydroxyl number of PKO-p was conducted using Karl Fischer Titrator (KFT) Model 787 KF Titrino according to ASTM E 1899-97(Standard test method for hydroxyl groups using reaction with p-toluene sulfonyl isocyanate (TSI) and potentiometric titration with tetrabutylammonium hydroxide). In this analysis, the hydroxyl groups were converted to an acidic carbamate with toluol-4-sulfonyl-isocyanate at room temperature. This was titrated with tetrabutylammonium hydroxide (TBAOH). Viscosity of the samples was measured using Brookfield Viscometer model DV-II and spindle no. 2 at room temperature.

\section{RESULTS AND DISCUSSION}

There are many parameters that could potentially influence the production of PKO-p. They could be the heating rate and its source, agitation speed, pressure difference and nitrogen gas flow to prevent oxidation. Referring to the reaction scheme in Figure 1, by ignoring the process control of the mentioned parameters means the reaction might lead to incomplete reaction or oxidation or reverse reaction or even 'overcooked' product. Thus, controlling at laboratory level is important to monitor these changes for taking a step further to upscaling production.

In this study, several hypotheses were made onto the reaction that might occur. Lowering the pressure (to a minimum vacuum pressure), high nitrogen gas flow rate, increasing the stirrer speed or even higher heating rate during the reaction might lead to the formation of oxidized product as shown in Figure 3. The later and also failure to withdraw water as a by-product from the system could

TABLE 1 . The varied operating parameters for the production of the PKO-p

\begin{tabular}{cccc}
\hline $\begin{array}{c}\text { PKO-p } \\
\text { Sample }\end{array}$ & $\begin{array}{c}\text { Heating Rate, } \\
{ }^{\circ} \mathrm{C} \cdot \mathrm{min}^{-1}\end{array}$ & $\begin{array}{c}\text { Pressure, } \\
\text { mbar }\end{array}$ & $\begin{array}{c}\text { Agitator Speed, } \\
\mathrm{rpm}\end{array}$ \\
\hline $\mathrm{C}$ & 2 & 400 & 200 \\
$\mathrm{~T}_{1}$ & 1 & 400 & 200 \\
$\mathrm{~T}_{2}$ & 4 & 400 & 200 \\
$\mathrm{P}_{1}$ & 2 & 200 & 200 \\
$\mathrm{P}_{2}$ & 2 & 800 & 200 \\
$\mathrm{~S}_{1}$ & 2 & 400 & 100 \\
$\mathrm{~S}_{2}$ & 2 & 400 & 400 \\
\hline
\end{tabular}

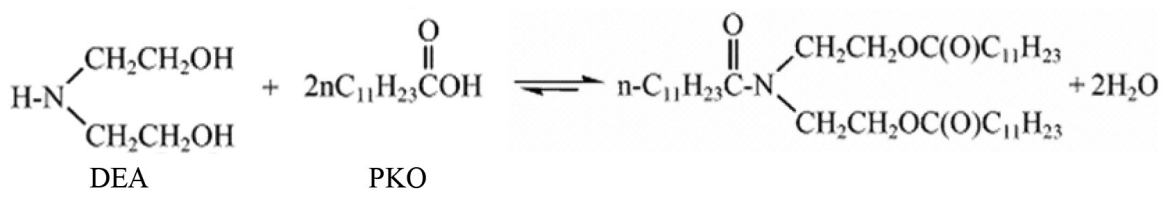

FIGURE 3. Occurrence of reversed reaction and oxidation in the synthesis of PKO-p 
also result in reversible reaction. At lower pressure, there is greater tendency for DEA, a low boiling point compound to be pumped out from the system. As a result, the occurrence of incomplete reaction would also be the risk.

The RBD PKO, a chain of fatty acid with carboxylic acid group displayed intense $\mathrm{C}=\mathrm{O}$ stretching bands of acids absorbing at $1711 \mathrm{~cm}^{-1}$ as shown in Figure 4. Peaks at 2932 and $2854 \mathrm{~cm}^{-1}$ were the alkyl stretching group $\left(-\mathrm{CH}_{2}\right.$ or $\left.-\mathrm{CH}_{3}\right)$. Peaks at $1320-1210$ and $1440-1395 \mathrm{~cm}^{-1}$ were from $\mathrm{C}-\mathrm{O}$ stretching and $\mathrm{O}-\mathrm{H}$ bending, respectively. Both bands involved some interactions between C-O stretching and C-O-H bending (Silverstein \& Francis 1998).

The FTIR spectrum of the synthesized PKO-p was evaluated at 3388 and $1622 \mathrm{~cm}^{-1}$ which are the hydroxyl $(-\mathrm{OH})$ and carbamate $(-\mathrm{CN})$ peaks, respectively, as shown in Figure 5. These two peaks did not appear in the spectrum of the raw RBD PKO. A peak detected at $1737 \mathrm{~cm}^{-1}$ was the carbonyl group of ester $(-\mathrm{C}=\mathrm{O})$ while peaks at 2924 and $2854 \mathrm{~cm}^{-1}$ were the alkyl $\left(-\mathrm{CH}_{2}\right.$ or $\left.-\mathrm{CH}_{3}\right)$ stretching peak
(Badri et al. 2000). The bench reaction vessel for the production of PKO-p has exhibited its capability to convert TAG of PKO to ester with OH terminals. Similar spectrum was obtained for each sample. The FTIR spectroscopy analysis was summarized in Table 2.

\section{EFFECT OF HEATING RATE ON THE PRODUCTION OF THE PKO-P}

To determine the effect of temperature on the esterification of the PKO-p, the heating rate was varied at three different rates that were 1,2 and $4^{\circ} \mathrm{C} / \mathrm{min}$ labeled as $T 1, C$ and $T 2$, respectively, as shown in Figure 6. These samples were analyzed by determining the moisture content, hydroxyl value, viscosity and yield percentage. The data was as tabulated in Table 3.

In addition, the operating time and temperature played significant roles in determining the completion of reaction. Since PKO is the limiting reactant, longer cooking time

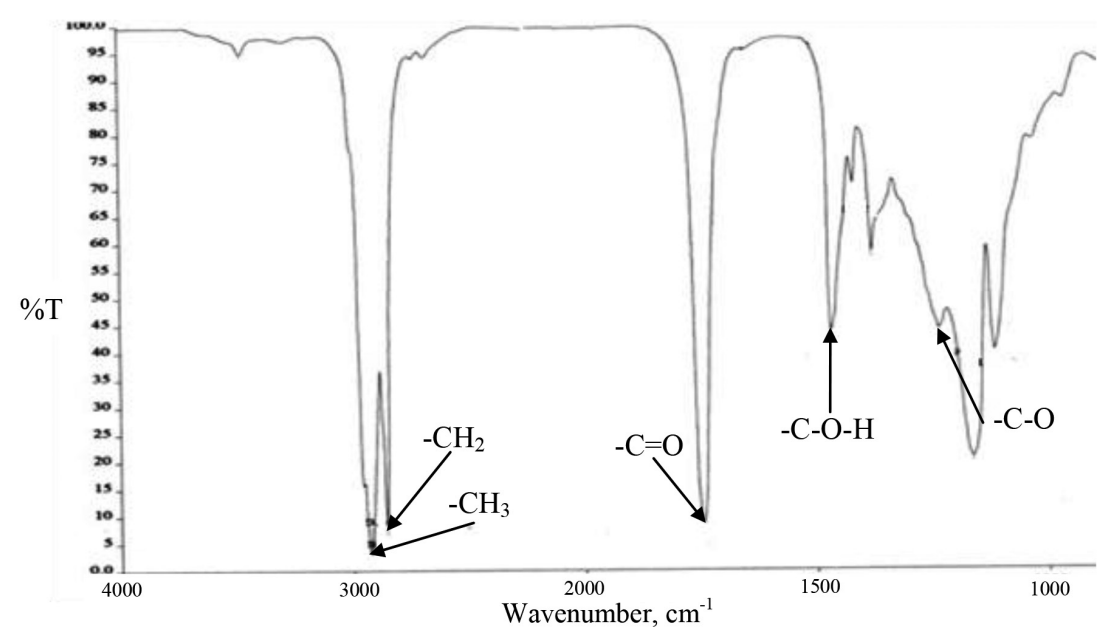

FIGURE 4. FTIR spectrum of the raw RBD PKO

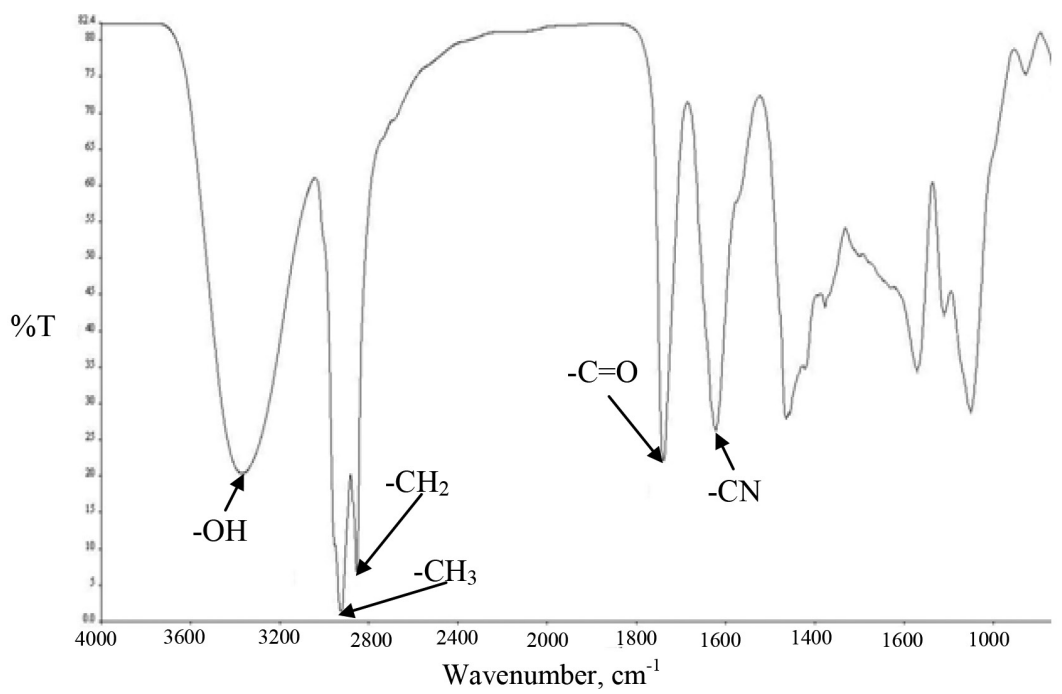

FIGURE 5. FTIR spectrum of PKO-p 
TABLE 2. Summarized data from the FTIR spectroscopy analysis of PKO-p produced at varying parameters

\begin{tabular}{lccccccc}
\hline Functional & \multicolumn{7}{c}{ Wavenumber, $\mathrm{cm}^{-1}$} \\
\cline { 2 - 8 } Groups & $C$ & $T_{1}$ & $T_{2}$ & $P_{1}$ & $P_{2}$ & $S_{1}$ & $S_{2}$ \\
\hline$-\mathrm{OH}$ & 3391 & 3379 & 3379 & 3391 & 3392 & 3392 & 3379 \\
$-\mathrm{CH}_{2}$ & 2923 & 2924 & 2925 & 2924 & 2925 & 2924 & 2921 \\
$-\mathrm{CH}_{3}$ & 2854 & 2854 & 2854 & 2854 & 2854 & 2854 & 2853 \\
$-\mathrm{C}=\mathrm{O}$ (ester) & 1739 & 1739 & 1738 & 1739 & 1739 & 1739 & 1739 \\
$-\mathrm{CN}$ & 1622 & 1626 & 1622 & 1622 & 1622 & 1622 & 1621 \\
\hline
\end{tabular}

Note (as tabulated in Table 2):

Sample $C$ follows the optimized processing parameters suggested by Badri et al. (2000)

Sample $T 1$ and $T 2$ were produced at varying heating rate

Sample $P 1$ and $P 2$ were produced at varying pressure

Sample $S 1$ and $S 2$ were produced at varying mixing velocity

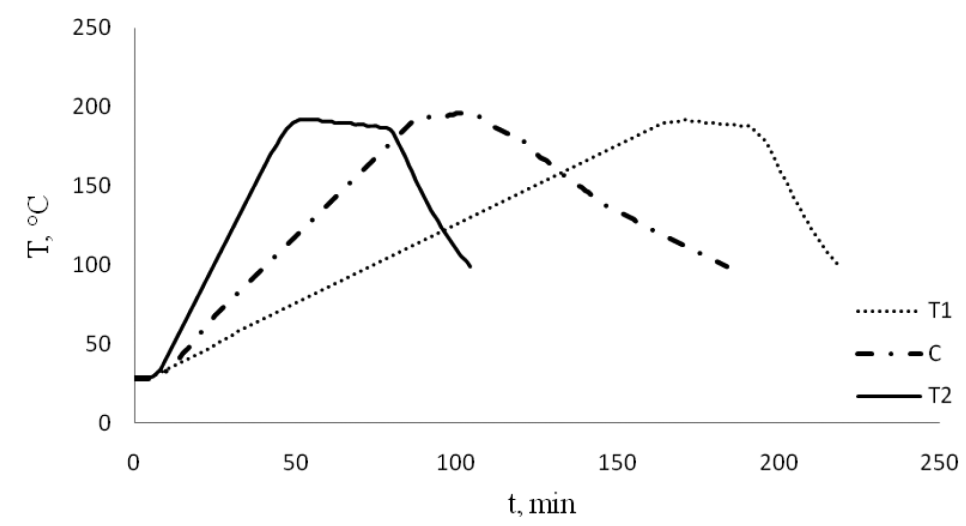

Note: $T 1$ Production of PKO-p at lower heating rate (slow production)

C follows the optimized processing parameters suggested by Badri et al. (2000)

T2 Production of PKO-p at high heating rate (faster production)

FIGURE 6. Optimization of process design on heating and cooling operations

TABLE 3. Moisture content, cloud point, $\mathrm{OH}$ value, viscosity and percentage of product yield of PKO-p at various processing variables

\begin{tabular}{cccccc}
\hline $\begin{array}{c}\text { PKO-p } \\
\text { samples }\end{array}$ & $\begin{array}{c}\text { Moisture content, } \\
\%\end{array}$ & $\begin{array}{c}\text { Cloud point, } \\
{ }^{\circ} \mathrm{C}\end{array}$ & $\begin{array}{c}\text { OH value, mg/g } \\
\mathrm{KOH}\end{array}$ & $\begin{array}{c}\text { Viscosity at } \\
25^{\circ} \mathrm{C}, \mathrm{cps}\end{array}$ & $\begin{array}{c}\text { Product Yield, } \\
\%\end{array}$ \\
\hline $\mathrm{C}$ & 0.06 & 12 & 355.65 & 427 & 95 \\
$\mathrm{~T}_{1}$ & 0.05 & 13 & 331.87 & 374 & 94 \\
$\mathrm{~T}_{2}$ & 0.07 & 12 & 360.46 & 410 & 96 \\
$\mathrm{P}_{1}$ & 0.13 & 12 & 308.84 & 478 & 98 \\
$\mathrm{P}_{2}$ & 0.06 & 13 & 343.86 & 309 & 92 \\
$\mathrm{~S}_{1}$ & 0.16 & 13 & 378.08 & 400 & 97 \\
$\mathrm{~S}_{2}$ & 0.07 & 12 & 336.34 & 399 & 95 \\
\hline
\end{tabular}

Note: Data shown were the average of at least five readings recorded during the tests

and higher temperature might result in greater tendency of creating ester of the free-fatty acid (ffa) linkage in both $\mathrm{OH}$ end of the dihydric compound (the DEA). This resulted in low hydroxyl value, OHV. T1 with lower heating rate gave lower yield but running at longer production time as exhibited in Figure 6.

The esterification of PKO was catalyzed by potassium salt (Badri et al. 2000) and produced water as a by-product. Longer residence time (time taken for the PKO-p to be in the reaction vessel) increased the possibility of longer exposure of PKO-p to water condensate. Table 3 showed that moisture content decreased when heating rate was decreased.

\section{EFFECT OF PRESSURE ON THE PRODUCTION OF THE PKO-P}

One of the most important methods to depress the backward reaction in order to improve the yield was by applying vacuum pressure. In this reaction, the vacuum pressure was varied. Three vacuum conditions were studied at 200 , 400 and 800 mbar labeled as P1, C and P2, respectively, as shown in Table 1 . Table 3 shows clearly that the increase 
in vacuum pressure (200 to 800 mbar) decreased the yield percentage from 98 to $92 \%$. At higher vacuum pressure, there was a greater tendency for volatile reactants such as DEA to be withdrawn from the system. However, at lower vacuum pressure (200 mbar), the PKO-p consisted of higher moisture content $(0.13 \%)$. This is due to the inability of water withdrawal from the condensation.

\section{EFFECT OF MIXING SPEED}

A compromised agitation speed is required to create a circulation flow in mixing the reactants into a homogenous system. At Reynolds number 2800 (1), the type of flow applied was a transient flow. A transitional flow is a mixture of laminar and turbulent flow, with turbulence in the center of the vessel and laminar flow near the edges. When the agitator speed was increased, a larger vortex may occur and possible to experience turbulent flow with Reynolds number of $\sim 4300$. The latter will result in withdrawal of the volatile reactants in the system due to increase in shear rate and frictional energy loss. However, lower agitator speed created more possibility for water entrapment during the polycondensation process and a non-uniform mixture. PKO-p produced by $S_{1}$ with lower agitator speed resulted in higher moisture content $(0.16 \%)$ and hydroxyl value (Table 3). The latter was contributed by the $\mathrm{OH}$ group of the water molecules.

Table 3 shows the physicochemical properties of the PKO-p at various operating parameters. Palm kernel oil is a golden yellow liquid at room temperature and solidified at $23^{\circ} \mathrm{C}$. It has a cloud point of $24-25^{\circ} \mathrm{C}$ (Badri et al. 2001). Upon completion of the esterification of PKO in producing the PKO-p with $\mathrm{OH}$ terminals, the cloud point was reduced to a much lower temperature. The cloud point of PKO-p was detected at $12-13^{\circ} \mathrm{C}$ applicable for any processing variables. According to Shioguci et al. (1999), the polyhydric compounds played a role in the reaction to produce polyol by lowering the cloud point. This parameter is important to ensure that the industrial requirement to chill the polyurethane monomers to at least $19-20^{\circ} \mathrm{C}$ is achievable. This is important to ensure that at later stage, the reaction between PKO-p and isocyanate to form polyurethane is handled at moderate kinetics in order to form uniform cellular structured foam (Wirpsza 1993). Donati and Paludetto (1997) has verified that a laboratory experiment played a significant stage to establish a large scale production of a product. A laboratory experiment could be useful to identify important parameters before upscaling the production. This can only be done in parallel to confirmation of the product properties.

Based on Table 3, P1 has the highest viscosity between 470-480 cps. The PKO-p obtained was produced at $2{ }^{\circ} \mathrm{C} \cdot \mathrm{min}^{-1}$ heating rate, running at $200 \mathrm{mbar}$ with agitation speed of $200 \mathrm{rpm}$. Yield percentage of the monoester-OH was at $98 \%$. The moisture content was at $0.13 \%$ due to low level of vacuum pressure which caused insufficient withdrawal of water. Esterification of the triacylglyceride produced esters consisted of any carbon chain from C8 to $\mathrm{C} 20$. When these esters were further reacted with the alkanolamine, it formed monoester-OH of higher yield at C12. At molecular weight of 477 (Badri et al. 2000), this resulted in a much viscous polyol. Thus, the viscosity was observed at the range of $309-478 \mathrm{cps}$. The optimum parameters were selected at $\mathrm{C}$, with $2^{\circ} \mathrm{C} \cdot \mathrm{min}^{-1}$ heating rate, running at 400 mbar with agitation speed of $200 \mathrm{rpm}$. This PKO-p was produced at $95 \%$ yield with OHV of 355.65 $\mathrm{mg} / \mathrm{g} \mathrm{KOH}$ and viscosity of an average $427 \mathrm{cps}$. This was a standard polyol with functionality of 3 suitable for rigid foam application.

\section{CONCLUSION}

The production of PKO-p with various parameters was successfully conducted within $2-3 \mathrm{~h}$ processing times. The optimum conditions were established at heating rate $2^{\circ} \mathrm{C}$, vacuum pressure 400 mbar and agitator speed $200 \mathrm{rpm}$. This yielded $95 \%$ conversion of PKO to PKO-p with OHV of an average of $355.65 \mathrm{mg} \mathrm{KOH} / \mathrm{g}$.

\section{ACKNOWLEDGMENTS}

This project was funded by Innovation Fund by Center of Innovation and Collaboration (PIK) under its grant No. UKM-IF-01-2011 and is currently financially supported by Cradle Funds Sdn Bhd under Ministry of Finance, Malaysia and 03-01-02-SF0949 under Ministry of Science and Technology, Malaysia. This project is parked under the management of UKM Technology Sdn Bhd under Mr Md. Fairuz Mat Isa, the project manager and heading towards commercialization.

\section{REFERENCES}

Badri, K.H., Othman, Z. \& Mohd Razali, I. 2005. Mechanical properties of polyurethane composites from oil palm resources. Iranian Polymer Journal 14(5): 987-993.

Badri, K.H., Shahaldin, F.H. \& Othman, Z. 2004. Indigenous coating material from palm oil-based polyamide. Journal of Material Science 39: 4331-4333.

Badri, K.H.,Ahmad, S.H. \& Zakaria, S. 2001. Production of highfunctionality RBD palm kernel oil-based polyester polyol. Journal of Applied Polymer Science 81: 384-389.

Badri, K.H., Ahmad, S.H. \& Zakaria, S. 2000. Development of zero ODP rigid polyurethane foam from RBD palm kernel oil. Journal of Material Science Letters 19: 1355-1356.

Benli, S., Yilmazer, Ü., Pekel, F. \& Özkar, S. 1998. Effect of fillers on thermal and mechanical properties of polyurethane elastomer. Journal of Applied Polymer Science 68: 1057-1065.

Chian, K.S. \& Gan, L.H. 1998. Development of a rigid polyurethane foam from palm oil. Journal of Applied Polymer Science 68: 509-515.

Couper, J.R., Penney, W.R. \& Fair, J.R. 2012. Chemical Process Equipment. 3rd ed. USA: Butterworth-Heinemann.

Donati, G. \& Paludetto, R. 1997. Scale up of chemical reactor. Catalysis Today 34: 483-533.

Guo, A., Javni, I. \& Petrovic, Z. 2000. Rigid polyurethane foams based on soybean oil. Journal of Applied Polymer Science 77: 467-473. 
Kurth, T.M., Kurth, R.A., Turner, R.B. \& Kreifels, L.P. 2006. Oxylated vegetable-based polyol having increased functionality and urethane materials formed using the polyol, US 7084230 .

Shioguci, K., Kuzui, H. \& Yuuki, A. 1999. Process of measuring cloud point of polyglycerol-fatty acid ester, process of evaluating properties, and process of producing, US 5883274.

Silverstein, R.M. \& Francis, X.W. 1998. Spectrometric Identification of Organic Compounds. 6th ed. New York: John Wiley \& Sons.

Tanaka, R., Hirose, S. \& Hatakeyama, H. 2007. Preparation and characterization of polyurethane foams using a palm oil-based polyol. Bioresource Technology 99: 3810-3816.

Wirpsza, Z. 1993. Properties of polyurethane. In Polyurethanes: Chemistry, Technology and Applications, (Ellis Horwood Series in Polymer Science and Technology). London: Ellis Horwood Ltd. pp. 118-121.
Faculty of Science and Technology

Universiti Kebangsaan Malaysia

43600 Bangi, Selangor Darul Ehsan Malaysia

*Corresponding author; email: kaybadri@ukm.edu.my

Received: 15 January 2014

Accepted: 15 November 2014 